\title{
Introduction to the special issue
}

\section{Christian Thibon}

\section{(2) OpenEdition}

\section{Journals}

Electronic version

URL: https://journals.openedition.org/eastafrica/429

DOI: 10.4000 /eastafrica.429

ISSN: 2790-1076

\section{Publisher}

IFRA - Institut Français de Recherche en Afrique

\section{Printed version}

Date of publication: 1 October 2012

Number of pages: 9-10

ISSN: 2071-7245

\section{Electronic reference}

Christian Thibon, "Introduction to the special issue", Les Cahiers d'Afrique de l'Est / The East African Review [Online], 46-1 | 2012, Online since 07 May 2019, connection on 10 December 2021. URL: http:// journals.openedition.org/eastafrica/429 ; DOI: https://doi.org/10.4000/eastafrica.429

This text was automatically generated on 10 December 2021.

Les Cahiers d'Afrique de l'Est / The East African Review 


\title{
Introduction to the special issue
}

\author{
Christian Thibon
}

1 Globally, vulnerable people and especially the elderly, children and the youth are often subjected to violence, exploitation and neglect. In particular, many of the children and youth in this category have little or no access to formal education, employment and livelihoods, healthcare and basic nutrition. Disability, which often leads to further vulnerability, has been on the increase in Africa due to factors such as war, malnutrition, poor access to health services and disease, has resulted in a large population being left out of the development arena. It is for this reason that in Kenya, addressing the needs of orphaned and vulnerable populations has become a policy issue which has been incorporated in the Millennium Development Goals (MDGs).

2 This special issue is a collection of papers presented at the national conference on research on disability in Kenya held on 31 March 2012 in Nairobi; it includes a second section that presents the findings of a post-graduate research done by Mathieu Merino on vulnerable children in Kenya. The first section presents the conference proceedings. The conference jointly organised by the Institute for French Research in Africa (IFRA) and Kenyatta University (KU) in liaison with the Kenya Umbrella for Children with Disability (KUCD) brought together stakeholders with special interest in research on disability issues and the translation of findings into Kenya's development agenda. The research papers raise pertinent issues on the definition and nature of life of people with disabilities. In his paper, Stanley Mutuma notes that the definition of ability in any given country dictates the measures that need to be put in place in order to deal with national challenges affecting people with disabilities. The legal system and the 2010 Kenyan Constitution, for instance, have for a long time been silent on the needs, challenges and prospects for dealing with people with disability, thus making it difficult for them to not only access but also claim their rights.

3 Mary Runo on her part notes that despite the presence of many institutions to educate, school and rehabilitate people with disabilities, the lives of the latter are not much improved due to inadequacy of opportunities in terms of attachments to reliable institutions where they would earn a decent living. Peter Bukhala however reminds that if given proper coaching and sufficient practice time, most individuals with 
intellectual disabilities could successfully compete alongside or against many of their non-disabled peers. In this perspective, Wangari Mwai is calling for a revisitation of our arts and specifically literature and "orature" which she sees as the doors to unveiling the hidden potential in persons with disabilities. This section also includes a proposal presented by Kenyatta University towards an national intensive and extensive survey on disabilities in Kenya, with a comparative interest on rural and urban situations on Makindu and Mathare valley.

4 Part two of the journal presents the findings on prevention and protection of vulnerable children in Kenya. Lamenting the failure of Kenya's government policy to protect such children, Mathieu Merino observes that many have been exploited as they live in garbage dumps and duka (shops) verandahs for the lack of abords and adequate care by the government. He also notes that while various non-state actors have attempted to protect the thousands of vulnerable children, their numbers have been swelling tremendously, thus making it difficult for non-governmental actors to manage the problem. He suggests that in order to deal with the problem there is need for all stakeholders, including parents, the government and its institutions mandated to target such children, as well as Kenyan civil society organisations, to ensure that public policy towards the children are clearly designed and adequately implemented for the betterment of the lives of these marginalised group of children.

\section{AUTHOR}

CHRISTIAN THIBON

IFRA's Director 